\title{
THE STUDY TOPIC OF HISTORY IN THE ROMANIAN PRIMARY EDUCATION CURRICULUM
}

\author{
Elena Andreea Trif-Boia \\ Asst. Prof., Babeș Bolyai University, Romania, boia andreea@yahoo.com
}

\begin{abstract}
The present study analyzes the presence of History as a study topic in primary education in Romania, as reflected in the main curricular documents approved by the Ministry of National Education - Framework Plan for Primary Education (Bucharest, 2013), the School Curriculum for the Fourth Grade (Bucharest, 2014) respectively. From a structural point of view, it begins by arguing the importance of studying history in early childhood. Subsequently, the analysis focuses on Romania and captures the place of History in the curricular documents for primary education, the purpose of its study, the targeted competencies, including the contribution of the discipline to the formation of the eight key competencies established at European level. Finally, the information means by which the four general competencies are intended to be achieved are briefly described, as well as the methodological suggestions regarding the teaching, learning and assessment activities.
\end{abstract}

Keywords: History, Teaching, Primary schools, Romania, curriculum.

\section{INTRODUCTION}

History is one of the disciplines with an important contribution in shaping the personality of students, a feature which advocates for its early introduction into the school curriculum. First, it fulfills an educational function, having an important role in the formation of local, national, European and universal identity. However, it also has a notable contribution in the rising of future citizens. Approaching History, its topics and the examples that are presented to students, promotes democracy, emphasizing the importance of respecting human rights and human dignity. Children learn the rules and norms that formed the basis of role models and are warned about the causes of the most notorious atrocities in history. On the other hand, studying history also favors the shaping of basic skills necessary for any citizen's involvement in solving the problems of the society in which one lives - critical analysis, multi-perspectivity, research, investigation, argumentation etc.

Regarding the importance of the topic study, we may hold as witness its early introduction in the school curriculum either as an autonomous discipline or as part of a more general field. In most European countries, history is compulsory from primary school, with 1-2 hours per week. Generally, the first approaches begin around the age of 10 . However, there are also countries where it begins earlier, such as the United Kingdom, Greece, Norway or Slovakia. UK first introduced the study of history from the age of 5, allocating $1 \mathrm{~h} /$ week (National curriculum in England..., 2013). In Greece, History is compulsory starting with primary school, as early as 8 years of age, with $2 \mathrm{~h} /$ week (History in the curriculum, 2010, 17), while in Norway it is studied alongside social studies in both ranges of 6-13 years, and 13, to 16 years of age (History in the curriculum, 2010, 31). Finally, in Slovakia, History and Geography are part of the educational field Nature and Science and are compulsory from the beginning of primary education, 6-10 years of age (History in the curriculum, 2010, 41). 
The present study focuses on History teaching in primary education in Romania, with an emphasis on curricular documents' provisions. From a structural point of view, it begins with the argumentation of the importance of studying History in early childhood, in order to later focus exclusively on Romanian primary education, highlighting the purpose of teaching this discipline, the number of hours, skills and contents, and the school curriculum's authors' methodological suggestions as specialists in the history and sciences of education, respectively.

\section{LEARNING HISTORY IN EARLY CHILDHOOD}

Although much discussion was devoted to the difficulties that learning history entails for children, there are studies that argue in favor of early age school curricular approaches to this discipline. They emphasize the ability of history to help young students understand the world in which they live, but also the need to lay down foundations of historical consciousness as early as possible. Thus, at the level of the European Union, in the report prepared during the conference on primary education, in 1983, attention was drawn to the imperative of studying History at this stage of schooling, stating that its omission would be completely "wrong" (Ann Low-Bee, 1997, 9). Children, the document explains, "must become familiar with historical processes as early as possible, must begin to learn a sense of the temporal world beyond the immediate, and identify historical testimonies in the environment in which they live and in society." (Ann Low-Bee, 1997, 9)

At the same time, a number of researchers drew attention to the topic, emphasizing the importance of studying children's History. Writing an article on early history teaching in education, Yngve Skjæveland, an education specialist at the Norwegian University of Science and Technology, argued for the need to study history in young children, pointing out that "although historical understanding in early childhood may be limited, teaching history in the education and care of the early child can lay the foundations of historical awareness and its further development in school" (Yngve Skjæveland, 2017, 8). In his investigation, Skjæveland also found the existence of an emerging historical consciousness in 5- and 6-year-olds (Yngve Skjæveland, 2017, 8). For her part, Hilary Cooper, historian and educator, professor at the University of Cumbria, UK, emphasized that the past is "a dimension of children's social and physical environment and they interact with it from birth" and put forward several arguments in support of that assertion: „they hear and use the vocabulary of time and change: old, new, yesterday, tomorrow, last year, before you were born, when mummy was little, a long time ago, once upon a time. They ask questions about the sequence and causes of events: when did we move here? Why? What happened in the story next? Children encounter different interpretations of past times in nursery rhymes and fairy stories, family anecdotes, theme parks, films and pantomime. They encounter historical sources: old photographs, a baby book, an ornament, a statue, a church, maybe a closed-down factory or a derelict cinema being replaced by new roads and flats ... before children start school there are many contexts in which they are implicitly aware of the past" (Hilary Cooper, 2002, 2). On the other hand, in the work "Doing History. Investigating with Children in Elementary and Middle Scools", Linda Levstik ${ }^{1}$ and Keith Barton ${ }^{2}$, education specialists, highlighted the challenges of teaching history, appreciating that young students can learn successfully as teachers make connections between the knowledge they already have and those to be obtained (Linda Levstik, Keith Barton, 2001, 45). To achieve this goal, the two authors suggested approaching the personal history and family history, showing that in this way students will understand that they also have their own history and that it is much more significant when they study it with other histories (Linda Levstik, Keith Barton, 2001, 45). Finally, Lynne Dixon and Alison Hales, specialists in the early education of students, argued that the purpose of history is to ensure understanding of the present world, and therefore there should be no age limit for learning it (Yngve Skjæveland, 2017, 9).

On the other hand, the experience of teaching history shows us that its early introduction in the school curriculum has a positive impact on students. Analyzing the British history curriculum, Dean Smart and Penelope Harnett of the University of the West of England pointed out that, although the study of history in Key Stage 1 students was viewed with some reluctance by specialists, school practice with more than two decades of teaching has shown the opposite: „children are excited by history and are capable of asking and answering questions about the past", the two authors emphasized (Dean Smart, Penelope Harnett, 2009, 107). In fact, these encouraging results led the authors of "The Early Years Foundation Stage Curriculum" (05 years) to suggest a series of activities for the development of historical thinking for preschoolers in the field of learning and development "Knowledge and understanding of the world" (Dean Smart, Penelope Harnett, 2009, 107).

\footnotetext{
${ }_{1}^{1}$ Professor in the Department of Curriculum and Instruction at the University of Kentucky, USA.

2 Professor in the Department of Curriculum and Instruction and Adjunct Professor of History at Indiana University, USA.
} 


\section{THE STUDY OF HISTORY IN THE CURRICULAR DOCUMENTS INTENDED FOR THE ROMANIAN PRIMARY EDUCATION}

In Romania, primary education is the first stage of compulsory general education (National education law, 2011, no. 1, Title II, Art. 16, para. 1). It begins around the age of 6, with the preparatory class (CP), and continues later, between 7 and 11 years, with grades I-IV. The official document guiding this level of study, the Framework Plan for Primary Education, was approved by the Ministry of National Education (MEN) on March 12, 2013 and sets out the subjects to be studied according to the various types of schools, their succession by years of study, the number of hours allocated weekly and annually to each object. The grouping of disciplines is carried out, according to their common features (skills, values and attitudes, targeted behavior), in seven curricular areas: Language and Communication; Mathematics and Natural Sciences; Man and Society; Physical Education, Sports and Health; Arts; Technologies; Counseling and Guidance.

Within this school level, History is studied as an independent discipline with only one hour per week, in the fourth grade. It is part of the Man and Society curriculum area, along with disciplines such as Geography, Civic Education and Religion, contributing to shaping students' personalities by familiarizing them with aspects of the past of their hometown, the Romanian people and the European peoples with whom a common history is inherited. The rule for organizing contents is passing from simple to complex: it begins with the analysis of some familiar facts, of some data related to the family's and the students' communities' past, in order to finish with the examination of some themes regarding facts that are situated "at a greater distance in time and space" (History School Curriculum for the Fourth Grade, 2014). At the same time, by the nature of the selected contents, the curriculum for this discipline aims at integrating the elements of local history in the national history and the latter in the universal history, thus responding to the requirements formulated at the level of the European Union (Ann Low-Beer, 1997; Recommendation 15 (2001) of the Committee of Ministers to Member States on History Teaching in Twenty-First-Century Europe).

In Romanian education, History, like other disciplines, contributes to the formation of the 8 key competences necessary for members of the knowledge-based society (Recommendation of the European Parliament and of the Council of 18 December 2006 on key competences for lifelong learning, (2006/962/EC)):

- Communication in the native language, because History lessons involve openness to dialogue, discussions, debates, issues which address the building of communication skills - reading historical texts or sources, understanding the text message, formulating arguments, expressing them correctly, coherently, logically, etc.;

- Civic and interpersonal skills, as History emphasizes values and their assumption in relationships with peers - solidarity, respect for other cultures and civilizations etc. -, provides data related to the fundamental documents underlying the modern state, studies political and civil rights, managing to capture their birth and evolution to the present day;

- Cultural awareness and expression, because its study results in awareness of the local, national, European and global cultural heritage and provides basic knowledge of the major cultural works of mankind;

- Skills in mathematics and elementary skills in technology, by working with chronology, analysis of graphs, calculation of the reign of some personalities or of the military effectives etc.;

- Skills in the use of new information and communication technologies, by accessing manuals and electronic interactive materials, by using online sources of information in order to write reports, leaflets, drawings, portfolios, etc.;

- Communication in foreign languages by studying the etymology of some specialized terms, the pronunciation of the names of some states, of some settlements outside the country, the names of some personalities from the European or world history or the names of some institutions;

- Initiative and entrepreneurship, as history offers countless examples of economic success or failure as a result of policies promoted by states over time;

- Adopting new competences by the offered tasks, meant to stimulate individual or group work, through the efficient management of the working time, through the acquisition of new knowledge and skills, specific to this discipline.

Based on the 8 key competencies highlighted above, "The 4th Grade History Curriculum" (2014), an official document issued by the Romanian Ministry of Education and Research, establishes the general and specific 
competencies that the History study must develop in primary education. The general competences are defined as sets of knowledge, skills and attitudes that are to be formed through learning and that allow the identification and solution of problems specific to the field (History School Curriculum for the Fourth Grade, $2014,2)$. They are competences with a high degree of generality, which are to be achieved during this educational cycle. The specific competences, in turn, are derived from the general ones and represent the particular stages of gradually achieving them, competencies formed during a single school year, respectively. They differ from one class to another, and mark the progress that students should make in the discipline. According to the document, the study of history in primary education contributes to the formation of the following general and specific skills:

1. The time and space setting of the studied historical events, which involve the chronological order of events in family life, the facts presented in a learning situation, the location in space of historical events, acknowledging people's pursuit for time and space significance.

2. Exploring relevant sources to understand past and present facts and events, respectively identifying historical sources using a variety of tools, including information and communication technologies, applying simple source analysis procedures to identify various information about the past, using historical sources for identifying the root causes, consequences and changing or unchanging elements in a certain period of time.

3. The use of historical terms in different communication situations, the recognition of historical terms in accessible sources, the correct use of accessible historical terms in oral and written communication situations.

4. Forming a positive image about oneself and others, determining the significance of past and present events, detecting similarities and differences between oneself and another, between people and groups, manifesting an open attitude in situations involving communication (History School Curriculum for the Fourth Grade, 2014).

The curriculum provides, by way of example, some suggestions for activities through which teachers would achieve the above competences. Generally, they are designed to promote active learning in history, through the use of modern teaching methods and means, by personally engaging students in order to develop their interest in the discipline: making role-plays / dramatizations of historical stories and legends, watching and discussing sequences from historical films or reports, observing digital maps and simulations of armed conflicts, making diaries, albums or posters, organizing exhibitions of drawings, paintings, collages on how the clothing of people in the past evolved, their tools, housing architecture etc.

The learning contents are presented according to a thematic criterion and contain elements of family history and local history, elements of history of the Romanian people and cohabiting peoples, as well as elements of European or universal history. Also, the study of aspects related to culture and heritage is promoted by introducing contents aimed at analyzing some historical places in the local community, some objectives of historical importance for Romania, as well as monuments and places included in the UNESCO heritage. In addition, it proposes a design principle that would capitalize on the school context, giving the teacher the opportunity to negotiate with students the option for certain topics of national or European history, depending on their interests, but also on the teaching resources available or the supporting elements provided by the educational institution. For example, in sections such as "Peoples of Yesterday and Today" or "Knowing the World by Travelers", the teacher is required to opt for at least one of the following contents in the program: "Dacians, Romans, Greeks, Gauls, Slavs, Turks, Romanians, French, Hungarians, Germans, Russians, Serbs and Bulgarians " (History School Curriculum for the Fourth Grade, 2014, 7), within the first theme, or "Marco Polo, Cristofor Columbus, Magellan, Badea Cârțan, Milescu the Swordbearer, Emil Racoviță, Alexander Csoma de Korosi, explorers of the 20th century" (History School Curriculum for the Fourth Grade, $2014,7)$, in the second.

\begin{tabular}{|l|l|}
\hline \multicolumn{1}{|c|}{ AREAS } & \multicolumn{1}{|c|}{ THEMES } \\
\hline $\begin{array}{l}\text { The past and the present of } \\
\text { around us }\end{array}$ & $\begin{array}{l}\text { Introductory notions: past-present, (millennium, century, decade, } \\
\text { historical epoch), historical space, historical sources } \\
\text { Family: family past, family holidays, free time, daily activities } \\
\text { Local and national community: territory, housing and daily life, traditions, } \\
\text { holidays, religion, monuments of heroes } \\
\text { Minority communities on the territory of today's Romania }\end{array}$ \\
\hline
\end{tabular}




\begin{tabular}{|c|c|}
\hline & $\begin{array}{l}\text { Yesterday's and today's childhood in the local community } \\
\text { Peoples of yesterday and today: location on the map, occupations, } \\
\text { traditions, customs, holidays } \\
\text { Knowing the world through travelers }\end{array}$ \\
\hline Ages, events and figures & $\begin{array}{l}\text { Antiquity } \\
\text { Legends and writings of the ancients about the Dacians and Romans } \\
\text { Middle Ages } \\
\text { Legendary figures of voivodes, rulers and local leaders in chronicles and } \\
\text { historical stories } \\
\text { Transylvania - multiethnic space. Village and town in Transylvania } \\
\text { medieval } \\
\text { Historians and chroniclers about minority personalities } \\
\text { Modern age } \\
\text { Al. I. Cuza and the Union } \\
\text { Carol I and independence, Carol Davila } \\
\text { Heroes of the First World War } \\
\text { Ferdinand and the Great Union } \\
\text { Romania at the turn of the millennia }\end{array}$ \\
\hline Culture and heritage & $\begin{array}{l}\text { Historic places in the community: monasteries, streets and historic } \\
\text { houses from the community, monuments of heroes, representative } \\
\text { monuments of ethnic communities in Romania } \\
\text { Places of historical importance for Romania: } \\
\text { - Dacian, Greek and Roman settlements and constructions (cities } \\
\text { Greeks on the Black Sea coast) } \\
\text { - Castles and fortresses witness to historical events } \\
\text { - Religious constructions and their founders } \\
\text { Monuments and places included in the UNESCO patrimony }\end{array}$ \\
\hline
\end{tabular}

Fig. 1 The contents of the 4th grade history school curriculum

For a comprehensive approach to history, the above-mentioned curricular document recommends teachers the interdisciplinary approach to learning and activities' assessment, offering, in this regard, some concrete examples of topics that would be integratedly addressed within the Man and Society curricular area. One of them refers to the topic of the local and national community, the contents of which can be taught both from the perspective of History and from the perspective of Geography, Civic Education or Religion, contributing to the formation of specific competences for each of the mentioned disciplines.

Finally, in terms of methodology, The 4th Grade History Curriculum offers suggestions aimed at supporting teachers in designing teaching activities. In general, teachers are encouraged to use student-centered teaching-learning-assessment strategies that encourage interaction, exercise their ability to work in a team, and lead to the development of their learning and critical thinking skills. Also, as a modern means of training, a strong proposition has been made for using computer in teaching activities in order to gain access to information and communication technology, but also to carry out interactive activities that stimulate students' interest in the subject.

\section{CONCLUSIONS}

History is a discipline with a notable contribution to students' personality shaping. Studies in the field show that its early introduction in the school curriculum helps children to better understand the world they live in and also lays the foundations of an emerging historical consciousness, thus facilitating the study completion of the discipline in later stages of schooling. 
In Romania, even if the study of History begins only around the age of 10, thus from the fourth grade onward, sporadic elements of local or national history are also included in preschool education within the "Man and society" curricular area. Thus, there are lessons conceived for familiarizing preschoolers with features related to local customs and traditions, acquainting with the name of the country of origin, with the symbols of the state or with some national customs and traditions.

In primary education, the study of History aims at training students in skills regarding the use of chronologies or historical maps, skills for identifying and analyzing historical sources, as well as skills for using specialized terms and forming a positive attitude to oneself and to others. The information media indicated by the school curriculum in order to achieve them are designed to cover both familiar content to students, the past of the family and the local community, and lesser-known topics related to national or European history. A rather ambitious plan, if one is to consider the low number of hours that this discipline benefits from (1h / week) as plainly noticed in the curricular document's text, which makes any employment of modern methods of teaching rather difficult since such methods by their nature are time consuming.

\section{REFERENCE LIST}

1. Bolovan, Paula Sorina (2007), Didactica istoriei: noi orizonturi în predarea, învăţarea şi evaluarea istoriei prin metode active (History teaching: new horizons in teaching, learning and evaluating history through active methods), PUC, Cluj-Napoca.

2. Cooper, Hilary (2002), History in the Early Years, Taylor \& Francis e-Library.

3. Felezeu, Călin (2004), Didactica istoriei (History teaching), PUC, Cluj-Napoca.

4. Gruber, Gabriela (2016), Didactica istoriei și formarea competențelor (History teaching and skills training), Ed. Cetatea de Scaun, Târgoviște.

5. History in the curriculum (Sept. 2010). Vezi

http://www.herrflynn.com/htai/docs/2012 docs/2012 eurydice stats history europe schools.pdf.

Address accessed on August 3, 2021.

6. National education law (2011), no. 1, Title II, Art. 16, para. 1

6. Levstik, Linda; Barton, Keith (2001) Doing History. Investigating with Children in Elementary and Middle Scools, 2nd ed., London.

7. Low-Beer, Ann (1997) Consiliul Europei și Istoria în școală (The Council of Europe and School History), Strasbourg,

8. National curriculum in England: history programmes of study, Department of Education, 11 September 2013. See https://www.gov.uk/government/publications/national-curriculum-in-england-historyprogrammes-of-study/national-curriculum-in-england-history-programmes-of-study. Address accessed on August 4, 2021

9. Planul cadru pentru învățământul primar (Framework Plan for Primary Education), București, 2013.

10.Programa școlară pentru disciplina Istorie (History School Curriculum for the Fourth Grade), clasa a IV-a, OMEN nr. 5003/02.12.2014, București, 2014

11. Recomandarea 15 (2001) privind Predarea istoriei în Europa în secolul 21, Consiliul Europei (Recommendation 15 (2001) of the Committee of Ministers to Member States on History Teaching in Twenty-First-Century Europe), Strasburg, 31 oct. 2001, trad. Mihai Manea.

12. Recommendation of the European Parliament and of the Council of 18 December 2006 on key competences for lifelong learning, (2006/962/EC). See https://eur-lex.europa.eu/legalcontent/RO/TXT/?uri=celex\%3A32006H0962. Address accessed on August 6, 2021

13.Smart, Dean; Harnett, Penelope (2009), The History Curriculum in England: Contested Narratives, în Teaching History and Social Studies for Multicultural Europe, Ankara, pp. 99-116.

14.Yngve Skjæveland, Learning history in early childhood: Teaching methods and children's understanding (2017), în Contemporary Issues in Early Childhood, Vol. 18(1) p. 8-22. 